\title{
Stres oksydacyjny w etiopatogenezie nieswoistych chorób zapalnych jelit
}

\begin{abstract}
STRESZCZENIE
$\mathbf{N}$ ieswoiste choroby zapalne jelit (NChZJ) stanowią grupe przewlekłych chorób zapalnych przewodu pokarmowego o złożonej i nie do końca poznanej etiologii. Wśród przyczyn ich powstawania znaczną rolę przypisuje się interakcji czynników genetycznych, środowiskowych i immunologicznych, których nieodłącznym elementem jest stres oksydacyjny. Dlatego tak istotne dla zachowania prawidłowej homeostazy komórkowej jest utrzymanie równowagi oksydoredukcyjnej $\mathrm{w}$ przewodzie pokarmowym, który jest $\mathrm{w}$ stałej ekspozycji na ogromną liczbę bakterii stanowiących część flory jelitowej, jak i patogennych. Zaburzenie tej homeostazy i nasilenie stresu oksydacyjnego prowadzą do propagacji stanu zapalnego, uszkodzenia błony śluzowej przewodu pokarmowego oraz wiążą się zarówno z rozwojem, jak i zaostrzeniami NChZJ.
\end{abstract}

\section{STRES OKSYDACYJNY}

Nieswoiste choroby zapalne jelit stanowią grupę przewlekłych chorób zapalnych przewodu pokarmowego, wśród których wyróżnia się przede wszystkim wrzodziejące zapalenie jelita grubego (WZJG) oraz chorobę Leśniowskiego Crohna (ChLC). We WZJG zapalenie błony śluzowej w początkowym okresie choroby obejmuje odbytnice i może stopniowo przez ciągłość zająć pozostałe części jelita grubego. ChLC może natomiast zaatakować każdy odcinek przewodu pokarmowego, przy czym najczęściej zlokalizowana jest $\mathrm{w}$ końcowym odcinku jelita cienkiego. Zapalenie ma charakter miejscowy oraz pełnościenny, często powikłany tworzeniem przetok, ropni i zwężeń światła jelita. ChLC podobnie jak WZJG charakteryzuje się zmiennym przebiegiem w postaci zaostrzeń i remisji.

Stres oksydacyjny to brak równowagi pomiędzy wytwarzaniem reaktywnych form tlenu (RFT) a zdolnościami antyoksydacyjnymi organizmu. Jako, że ponad $90 \%$ tlenu komórkowego wykorzystywane jest przez mitochondria $\mathrm{w}$ procesie fosforylacji oksydacyjnej, to właśnie mitochondria są głównym źródłem RFT. Fosforylacja oksydacyjna, czyli główny i najbardziej wydajny proces wytwarzania energii przez organizm ludzki, oparta jest o łańcuch transportu elektronów, których ostatecznym akceptorem jest właśnie tlen, przechodząc $\mathrm{w}$ trakcie czterostopniowej redukcji do cząsteczki wody [1,2]. Wysoko reaktywne formy tlenu, które wówczas powstają, prowadzą do reakcji łańcuchowych, w których jeden wolny rodnik, czyli atom, jon lub cząsteczka posiadająca niesparowany elektron rozpoczyna reakcję niszczącą szereg molekuł. Jednym z najistotniejszych przykładów jest proces peroksydacji lipidów, w którym dochodzi do reakcji pomiędzy RFT a wielonienasyconymi kwasami tłuszczowymi (WKT). WKT odgrywają znaczącą rolę nie tylko jako składnik budulcowy błony komórkowych, ale również jako istotny czynnik immunomodulujący. Liczne dane literaturowe dowodzą ich roli $\mathrm{w}$ proliferacji limfocytów, produkcji cytokin, fagocytozie i apoptozie komórek, co prowadzi do zmniejszenia odpowiedzi zapalnej organizmu [3,4]. Należy w tym przypadku zauważyć, że zainicjowana reakcja łańcuchowa przez pojedynczy wolny rodnik może spowodować uszkodzenie nawet 400 różnych cząsteczek, zanim zostanie zneutralizowana. Pokazuje to niezwykłą szkodliwość wolnych rodników i tym samym rolę antyoksydantów i ich znaczenie w utrzymaniu homeostazy oksydacyjnej organizmu. Co więcej, uszkodzenie lipidów błony komórkowej prowadzi do wzrostu jej przepuszczalności i akumulacji m.in. jonów wapnia wewnątrz komórki. Powoduje to z kolei aktywację fosfolipazy A2 odpowiedzialnej za dalszą degradację błony komórkowej i uwalnianie z niej kwasu arachidonowego, który jest podstawowym substratem w syntezie aktywnych biologiczne związków m.in. o charakterze prozapalnym (prostaglandyny, leukotrieny, itp.). W trakcie przemiany kwasu arachidonowego z udziałem cyklooksygenaz i lipooksygenaz wytwarzają się również dodatkowe ilości RFT, napędzając tym samym spiralę zniszczeń

\section{dr Michał Kloska ${ }^{1,2 \varpi,}$}

dr Dorota Mańkowska-Wierzbicka²,

dr Magdalena Człapka-Matyasik $^{3}$,

prof. dr hab. Agnieszka Dobrowolska²,

\author{
prof. dr hab. Marian Grzy- \\ misławski ${ }^{2}$
}

${ }^{1}$ Department of Medicine, Lehigh Valley Health Network, Allentown, Pennsylvania, USA ${ }^{2}$ Katedra i Klinika Gastroenterologii, Dietetyki i Chorób Wewnętrznych Uniwersytetu Medycznego im. Karola Marcinkowskiego w Poznaniu ${ }^{3}$ Wydział Nauk o Żywności i Żywieniu, Uniwersytet Przyrodniczy w Poznaniu

https://doi.org/10.18388/pb.2020_324

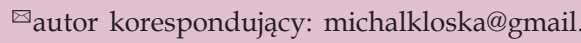
com

Słowa kluczowe: Nieswoiste choroby zapalne jelit, stres oksydacyjny, antyoksydanty, wolne rodniki, reaktywne formy tlenu.

Stosowane skróty: AOPP - zaawansowane produkty utlenienia białek (ang. advanced oxidation protein products), CDAI - skala aktywności choroby Leśniowskiego - Crohna (ang. Crohn's Disease activity index), GPx - peroksydaza glutationowa (ang. glutathione peroxidase), GR - reduktaza glutationowa (ang. glutathione reductase), GSH - glutation zredukowany, GSSG - utleniona postać glutationu, MDA dialdehyd malonowy (ang. malonyldialdehyde), MPO - mieloperoksydaza (ang. myeloperoxidase), NChZJ - nieswoiste choroby zapalne jelit, OB - odczyn Bienackiego, RFT - reaktywne formy tlenu, SOD - dysmutaza ponadtlenkowa (ang. superoxide dismutase), WR - wolne rodniki 
dokonanych przez wolne rodniki (WR) [1]. Podobnie toksyczne właściwości RFT udowodniono w stosunku do białek i kwasów nukleinowych, prowadzące między innymi do utlenienia zasad azotowych nukleotydów, rozwinięcia podwójnej nici DNA, tworzenia wiązań sieciujących czy adduktów białkowych. Ta modyfikacja struktur białek i kwasów nukleinowych prowadzi do utraty przez nie funkcji biologicznych. Co więcej, niektóre produkty utleniania białek mają również właściwości cytotoksyczne [5-7].

\section{ANTYOKSYDANTY}

Ze względu na wyjątkowo destrukcyjne działanie wolnych rodników, organizmy żywe wykształciły szereg mechanizmów obronnych, opartych o działanie antyoksydantów. Antyoksydanty ze względu na rolę w odpowiedzi na stres oksydacyjny dzieli się na prewencyjne, zmiatające i unieszkodliwiające już powstałe WR oraz naprawcze. Antyoksydanty prewencyjne zapobiegają tworzeniu WR, są to białka wiążące jony żelaza, miedzi, uniemożliwiające przebieg reakcji Fentona, należą do nich albumina, ferrytyna, transferryna i inne. Drugą grupę stanowią antyoksydanty zmiatające i unieszkodliwiające już powstałe WR, m.in. dysmutaza ponadtlenkowa (SOD, ang. superoxide dismutase), peroksydaza glutationowa (GPx, ang. glutathione peroxidase), nisko- i wielkocząsteczkowe, w tym witaminy A, E, C, glutation, kwas moczowy, bilirubina, polifenole, czyli egzoi endogenne antyoksydanty. Ich działanie polega na przerwaniu łańcucha wytwarzania wolnych rodników. Ostatnią grupę stanowią antyoksydanty pełniące funkcje naprawcze, czyli enzymy naprawiające uszkodzone lipidy, białka np. lipazy, aminotransferazy, enzymy naprawiające kwasy nukleinowe [8]. Antyoksydanty biorą udział w złożonym cyklu często zależnych od siebie reakcji, mających na celu zmniejszenie potencjału oksydacyjnego środowiska. SOD występuje w postaci 3 izoform: SOD1 (CuZnSOD), SOD2 (MnSOD) i SOD3 (ecSOD, ang. extracellular - pozakomórkowa), każda izoforma jest produktem innego genu oraz różni się lokalizacją w obrębie komórki, jednak wszystkie katalizują tą samą reakcję - dysmutację anionorodnika ponadtlenkowego [9]. Powstający nadtlenek wodoru jest następnie neutralizowany za pomocą katalazy, bądź peroksydazy glutationowej. GPx występująca głównie w cytozolu oraz w mniejszych ilościach w mitochondriach i jądrze komórkowym, odpowiedzialna jest za redukcję nadtlenku wodoru, jak również nadtlenków organicznych, w tym wodoronadtlenków lipidowych. Podstawowa reakcja katalizowana przez GPx zachodzi z udziałem zredukowanego glutationu (GSH). Glutation w formie zredukowanej jest jednym z najważniejszych antyoksydantów występujących w organizmie człowieka, jak również występuje w największej ilości. $\mathrm{U}$ osób zdrowych stosunek glutationu $\mathrm{w}$ formie zredukowanej do utlenionej (GSSG) wynosi 10:1. Z formy utlenionej glutation redukowany jest do GSH za pomocą reduktazy glutationowej (GR) przy udziale NADPH. Nasilenie stresu oksydacyjnego w organizmie prowadzi do obniżenia stężenia GSH, co koreluje ze zmniejszeniem potencjału antyoksydacyjnego organizmu [10]. Badania sugerują, że dodatkową rolę w przywróceniu stężenia GSH odgrywają również witamina C i E [11]. Istotą działania witaminy C jako antyoksydanta jest jej zdolność do oddawania elektronów, tym

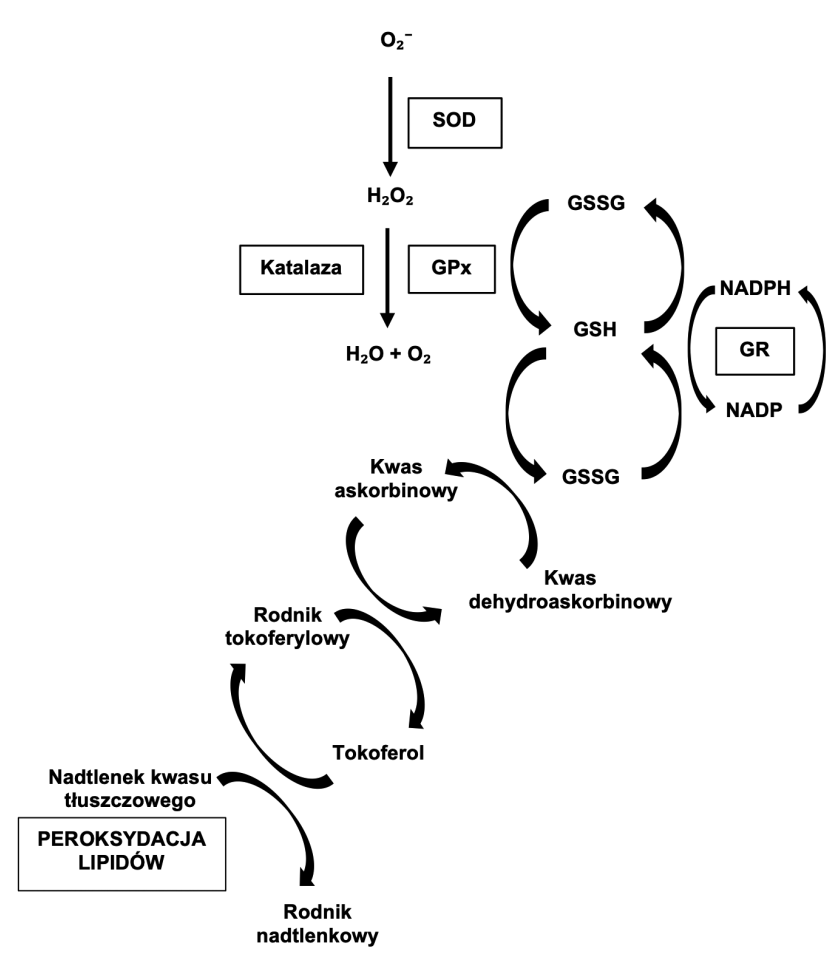

Rycina 1. Mechanizm obrony antyoksydacyjnej. 1. Anionorodnik ponadtlenkowy $\left(\mathrm{O}_{2}^{-}\right)$w reakcji katalizowanej przez SOD wiąże jeden elektron i dwa jony wodoru prowadząc do powstania nadtlenku wodoru $\left(\mathrm{H}_{2} \mathrm{O}_{2}\right) \cdot 2 . \mathrm{H}_{2} \mathrm{O}_{2}$ ulega redukcji do cząsteczki wody przy udziale katalazy lub peroksydazy glutationowej (GPx). 3. Zredukowany glutation jest odtwarzany przy udziale reduktazy glutationowej (GR). 4. Witamina E (tokoferol) usuwa produkty peroksydacji lipidów przekształcając się w rodnik tokoferylowy. Rodnik ten ulega regeneracji kosztem witaminy C, która ulega przekształceniu w kwas dehydroaskorbinowy. Witamina C jest odtwarzana natomiast przy udziale zredukowanego glutationu (GSH).

samym może ona zmniejszać nasilenie stresu oksydacyjnego i przywracać właściwości antyoksydacyjne witaminy E [12]. Dodatkowo, witamina C poprawia przepływ krwi w mikrokrążeniu, przywracając tym samym właściwą odpowiedź skurczową naczyń, a ponadto uszczelnia barierę nabłonkową, najprawdopodobniej na skutek zmniejszenia nasilenia stresu oksydacyjnego [13]. Mechanizm obrony antyoksydacyjnej został przedstawiony na rycinie 1 .

\section{STRES OKSYDACYJNY W NIESWOISTYCH CHOROBACH ZAPALNYCH JELIT}

Pomimo ogromnego zainteresowania etiopatogenezą NChZJ i dotychczasowych osiągnięć naukowych pozwalających zrozumieć mechanizmy wpływające na ich rozwój, nadal nieznane są dokładnie procesy warunkujące przebieg tych chorób. Wiadomym jest, że u ich podłoża leżą czynniki genetyczne, immunologiczne i środowiskowe, a mechanizmem pośrednim każdego z nich jest stres oksydacyjny. Homeostaza jest utrzymywana za pomocą antyoksydantów, które neutralizują RFT, przeciwdziałając tym samym uszkodzeniu struktur wewnątrzkomórkowych. Należy tu podkreślić, że przewód pokarmowy jest w stałej ekspozycji na ogromną liczbę bakterii i grzybów stanowiących część flory jelitowej, która w przebiegu NChZJ częściej kolonizowana jest przez drobnoustroje patogenne, a uszkodzenie błony śluzowej przez proces zapalny zwiększa dodatkowo ekspozycje komórek na działanie patogenów. Stwarza to proces błędnego koła, gdzie napływ komórek zapalnych 
zwiększa przepuszczalność bariery jelitowej, a napływ patogenów dalej nasila proces zapalny. NChZJ należy również traktować jak choroby układowe, jako że choroba nie ogranicza się do przewodu pokarmowego, a prowadzi do zaburzeń większości układów organizmu człowieka. Dotychczasowo przeprowadzone badania dotyczące opisywanych parametrów wskazują na często sprzeczne ze sobą wyniki badań. Związane jest to $\mathrm{z}$ wpływem licznych czynników warunkujących nasilenie stresu oksydacyjnego, w tym palenia papierosów, diety, niedożywienia, leków, czynników środowiskowych i wielu innych.

\section{ZAAWANSOWANE PRODUKTY UTLENIENIA BIAŁEK (AOPP)}

Stres oksydacyjny prowadzi do zmiany struktury białek, które wówczas przekształcane są w zaawansowane produkty utlenienia białek ( $\mathrm{z}$ ang. advanced oxidation protein products, AOPP). Są one powszechnie uznane za wiarygodny marker, a nawet mediator prozapalnego efektu stresu oksydacyjnego [14]. AOPP są przede wszystkim produktami przemiany albumin. Posiadają one zdolność stymulacji tzw. wybuchu tlenowego, czyli nagłego uwolnienia dużej ilości RFT przez neutrofile oraz indukują produkcję czynników chemotaktycznych dla komórek zapalnych $[15,16]$. Niewiele jest jednak doniesień dotyczących produktów utlenienia białek w NChZJ. Krzystek-Korpacka i wsp. przeanalizowali stężenie AOPP $\mathrm{w}$ surowicy $\mathrm{u}$ chorych na WZJG i ChLC w porównaniu z grupą kontrolną, jak również zwrócili uwagę na ich stężenie w zaostrzeniach tych chorób. Udowodnili oni statystycznie istotne różnice $\mathrm{w}$ stężeniu AOPP pomiędzy grupą kontrolną, a grupą chorych na WZJG i ChLC. Nie wykazali zaś różnic pomiędzy aktywną i nieaktywną postacią tych chorób. W przypadku ChLC stwierdzili natomiast istotnie statystyczną korelację $\mathrm{z}$ nasileniem choroby $\mathrm{w}$ skali aktywności choroby Leśniowskiego - Crohna (CDAI, ang. Crohn's Disease activity index) [17]. Alagozlu H. i wsp. wykazali zwiększenie stężenia AOPP u osób z zaostrzeniem WZJG, w porównaniu z remisją i grupą kontrolną. Nie wykazali natomiast różnicy pomiędzy chorymi w remisji a grupą kontrolną [18]. Zwiększenie AOPP u osób z WZJG w porównaniu z grupą kontrolną wykazali natomiast Baskol i wsp. Nie badali oni jednak korelacji AOPP z nasileniem choroby [19]. Co istotne, w żadnym z ww. badań nie wykazano różnic dotyczących płci, wieku czy czasu trwania choroby.

\section{IZOPROSTANY}

Izoprostany są produktem utleniania kwasu arachidonowego przez wolne rodniki. Cracowski i wsp. jako pierwsi zainteresowali się rolą izoprostanów w NChZJ. Przebadali oni grupę 23 pacjentów z ChLC i wykazali zwiększenie wydalania 8-izoprostaglandyny F2a typu III z moczem u chorych z zaostrzeniem w porównaniu z grupą kontrolną (23 osoby). Stwierdzili oni również korelację jego stężenia w moczu ze stężeniem markeru zapalnego CRP w surowicy chorych, nie wykazali jednak różnicy w jego stężeniu pomiędzy chorymi w remisji a grupą osób zdrowych [20]. Podobne rezultaty przedstawili Wendland B. i wsp., wykazując istotne zwiększenie stężenia izoprostanów F2 w surowicy pacjentów w porównaniu z grupą kontrolną [21].
W przypadku wrzodziejącego zapalenia jelita grubego brak jest dostępnych publikacji opisujących rolę izoprostanów w NChZJ in vivo, natomiast publikacje dotyczące indukowanego zapalenia jelit u myszy wskazują na wzrost stężenia 8-izoprostanu wydalanego z moczem, jak również na zwiększenie stężenia izoprostanów w błonie śluzowej jelita grubego [22].

\section{MDA - DIALDEHYD MALONOWY}

Dialdehyd malonowy (ang. malonyldialdehyde) jest produktem peroksydacji wielonienasyconych kwasów tłuszczowych. Peroksydacja lipidów będących elementem składowym błon komórkowych wpływa na ich funkcję głównie poprzez zmniejszenie elastyczności i zwiększenie przepuszczalności. MDA cechuje zdolność do tworzenia adduktów z białkami oraz RNA i DNA, co prowadzi do nagromadzenia szkodliwych mutacji [23]. Większość badań dotyczących roli MDA dowodzi ich zwiększonej produkcji w NChZJ. Boehm i wsp. wykazali zwiększone stężenie MDA w osoczu u osób chorych na ChLC zarówno w zaostrzeniu jak i w remisji, w porównaniu z grupą kontrolną [24]. Beltran i wsp. wykazali wzrost stężenia MDA w surowicy u chorych na ChLC, zarówno w przypadku zaostrzenia jak i remisji [25]. Nie wykazali oni różnic pomiędzy osobami palącymi i niepalącymi chorującymi na tę chorobę. Tüzün i wsp. w grupie chorych na WZJG oraz ChLC. nie wykazali zwiększenia stężenia MDA u osób z NChZJ (a w przypadku pacjentów $\mathrm{w}$ remisji wykazali nawet jego zmniejszenie), ale nie wykazali również istotnych korelacji pomiędzy pacjentami w zaostrzeniu i w remisji. Dokonali oni również porównania stężenia MDA w zaostrzeniu i remisji WZJG z zaostrzeniem i remisją w ChLC, jednak nie wykazali statystycznie istotnych różnic [26]. Alzoghaibi i wsp. również zwrócili uwage na porównanie obu jednostek chorobowych. W grupie 42 chorych na NChZJ stwierdzono statystycznie istotne zwiększenie stężenia MDA w surowicy krwi u chorych na ChLC w porównaniu z grupą kontrolną [18]. Podobne rezultaty we WZJG zaprezentował zespół Baskol i wsp., wskazując na statystycznie istotną różnicę i zwiększenie stężenia MDA u chorych z WZJG a osobami z grupy kontrolnej [19].

\section{OXLDL - UTLENIONE LIPOPROTEINY NISKIEJ GĘSTOŚCI}

Utlenione LDL (oxLDL, ang. oxidized low-density lipoprotein) są opisane w literaturze przede wszystkim jako czynniki nasilające proces aterogenezy w ścianie naczyń. Niezależnie jednak od tego procesu, powstanie oxLDL nasila migrację i aktywację komórek zapalnych, ogranicza funkcje LDL jako transporterów $\mathrm{m}$. in witamin rozpuszczalnych $\mathrm{w}$ tłuszczach, jak i również destabilizuje błonę komórkową [27]. Również w przypadku oxLDL dostępne są pojedyncze badania określające ich rolę w NChZJ. Rezultaty tych badań są sprzeczne, jako, że Boehm D. i wsp. nie wykazali zwiększenia stężenia oxLDL w porównaniu z grupą kontrolną, co więcej zaobserwowali statystycznie istotną negatywną korelację oxLDL z zaostrzeniem ChLC w skali CDAI, podczas gdy Grip O. i wsp. wykazali wzrost stężenia oxLDL w surowicy chorych na ChLC, jednak na bazie mniej licznej grupy badanej $[24,28]$. Analiza podobnej roli oxLDL we WZJG nie została natomiast przeprowadzona do tej pory. 


\section{DYSMUTAZA PONADTLENKOWA (SOD)}

Dysmutaza ponadtlenkowa odpowiedzialna jest za dysmutację anionorodnika ponadtlenkowego $\left(\mathrm{O}^{-*}\right)$ do nadtlenku wodoru i tlenu [9]. W ChLC wykazano statystycznie istotne zwiększenie aktywności SOD w surowicy u chorych $\mathrm{z}$ zaostrzeniem choroby $\mathrm{w}$ porównaniu $\mathrm{z}$ grupą kontrolną. Stwierdzono również, że aktywność SOD wraca do normy w przypadku osiągnięcia remisji u osób z ChLC i jej stężenie pozostaje wówczas porównywalne ze stężeniem SOD u osób zdrowych [25,29]. Odmienne wyniki uzyskali Alzoghaibi M. i wsp., którzy przebadali grupę 42 osób chorych na ChLC oraz 38 zdrowych osób i wykazali statystycznie istotne zmniejszenie aktywności SOD w surowicy osób chorych. Badanie to nie uwzględniało jednak podziału osób chorych według zaostrzenia choroby i jego znaczenia w regulacji stężenia SOD u tych chorych [30]. Podobne rezultaty przedstawili również Verspaget H.W. i wsp., którzy wykazali istotne zmniejszenie aktywności SOD zarówno u osób chorujących na ChLC, jak i również WZJG [31]. Mohhamadi E. i wsp. również wykazali zmniejszenie aktywności SOD zarówno w przypadku ChLC jak i WZJG [32]. Na istotny aspekt zwrócił uwagę zespół Szczeklika K., przedstawiając aktywność SOD w ślinie i surowicy chorych na ChLC. Autorzy wykazali negatywną korelację pomiędzy stężeniem SOD a stopniem zaostrzenia w skali CDAI. Zwrócili również uwagę na korelację pomiędzy poziomem aktywności SOD i parametrami stanu zapalnego, wskazując na jego negatywną korelację z CRP i stężeniem płytek krwi (PLT) u osób z ChLC [33]. Krzystek-Korpacka i wsp. natomiast wykazali negatywną korelację pomiędzy stężeniem SOD a kolejnym markerem zapalenia - OB w ChLC [34].

\section{GLUTATION ZREDUKOWANY (GSH)}

Glutation zredukowany jest jednym z najważniejszych antyoksydantów w organizmie człowieka. Lantomasi T. i wsp. przebadali grupę chorych na ChLC analizując stężenie glutationu w bioptatach z jelita cienkiego. Wykazali, iż w przypadku wycinków błony śluzowej pobranej od osób chorych z zarówno zmienionego chorobowo, jak również z prawidłowo prezentującego się odcinka jelita, stężenie glutationu jest niższe $\mathrm{w}$ porównaniu ze stężeniem $\mathrm{w}$ wycinkach pobranych od osób z grupy kontrolnej [35]. Podobne wyniki uzyskali Miralles-Barrachina O. i wsp, przy czym zwrócili oni również uwagę na stan odżywienia chorych i zaobserwowali zmniejszone stężenie GSH także w wycinkach $\mathrm{z}$ niezmienionego zapalnie odcinka jelita u osób niedożywionych z ChLC [36]. Rana SV. i wsp. dokonali natomiast pomiaru stężenia GSH w erytrocytach pozyskanych od chorych i jednocześnie stwierdzili istotne zmniejszenie stężenia GSH u chorych w porównaniu z grupą kontrolną [37]. Podobne wyniki wskazujące na zmniejszenie stężenia GSH wykazano w bioptatach błony śluzowej jelita grubego u osób z WZJG [38].

\section{PEROKSYDAZA GLUTATIONOWA (GPX)}

Szczeklik K. i wsp. zwrócili także uwagę na stężenie GPx w ślinie i surowicy osób z ChLC, nie wykazali jednak istotnych różnic ani pomiędzy GPx a CDAI ani pomiędzy stężeniem GPx w zaostrzeniu a grupą kontrolną. Nie stwierdzo- no również korelacji GPx z parametrami stanu zapalnego jak CRP, WBC czy PLT [33]. Dane te kontrastowały z wynikami badania Tüzün A. i wsp., którzy w surowicy chorych z ChLC i WZJG w porównaniu z grupą kontrolną wykazali zwiększenie aktywności GPx zarówno w przypadku zaostrzenia jak i remisji NChZJ. Nie stwierdzili natomiast różnic pomiędzy jego stężeniem $\mathrm{w}$ zaostrzeniu $\mathrm{w}$ porównaniu z remisją [26]. Odmienne wyniki badań przedstawili Krzystek-Korpacka i wsp., którzy po przebadaniu znacznej grupy chorych (93 pacjentów z ChLC oraz 81 pacjentów z WZJG) wykazali statystycznie istotne zmniejszenie aktywności GPx w aktywnej postaci choroby, zarówno w ChLC jak i we WZJG, w porównaniu do pacjentów w remisji oraz osób z grupy kontrolnej. Nie wykazali natomiast różnicy pomiędzy aktywnością GPx w zaostrzeniu i remisji ChLC ani we WZJG. Co więcej wykazano istotne statystycznie negatywne korelacje pomiędzy GPx, a CRP, WBC, PLT oraz OB w ChLC, natomiast w przypadku WZJG negatywna korelacja istniała tylko pomiędzy aktywnością GPx a CRP, WBC oraz PLT [34].

\section{REDUKTAZA GLUTATIONOWA (GR)}

W dostępnej literaturze opublikowano nieliczne doniesienia dotyczące wpływu NChZJ na aktywność reduktazy glutationowej (GR). Bhaskar L. i wsp. przeprowadzili analizę wycinków zmienionej zapalnie błony śluzowej jelita u chorych na WZJG oraz niezmienionej błony śluzowej pobranej od pacjentów z grupy kontrolnej. Nie wykazano statystycznie istotnej różnicy $\mathrm{w}$ aktywności GR pomiędzy chorymi na WZJG a osobami z grupy kontrolnej w tych wycinkach [39].

\section{WITAMINA C}

Imes S. i wsp. już ponad 30 lat temu zwrócili uwagę na zmniejszenie spożycia pokarmów bogatych $\mathrm{w}$ witaminę $\mathrm{C}$ przez osoby chorujące na ChLC. Wykazali oni również obniżenie stężenia witaminy $\mathrm{C}$ w surowicy u $18 \%$ mężczyzn i aż $37 \%$ kobiet chorujących na ChLC w porównaniu z osobami zdrowymi, zwracając tym samym uwagę na rolę suplementacji witamin $w$ tej jednostce chorobowej [40]. Odpowiednia ich suplementacja jest istotna, gdyż nawet u pacjentów w remisji często stwierdza się hipowitaminozę [41]. Co więcej, niektóre badania wykazały nawet zmniejszenie stężenia witaminy $\mathrm{C}$ u pacjentów z ChLC z prawidłową podażą witaminy $\mathrm{C}$ w diecie. $\mathrm{W}$ tym celu Wendland B. i wsp. wykluczyli z grupy badanej osoby niedożywione oraz palące i poddali osoby chore na ChLC ścisłej diecie w celu wykluczenia niedoborów witaminy C. Rezultaty potwierdziły statystycznie istotną różnicę pomiędzy stężeniem witaminy $\mathrm{C}$ u osób chorych $\mathrm{w}$ porównaniu $\mathrm{z}$ grupą kontrolną. Badacze zaobserwowali również negatywną korelację stężenia witaminy C z zaostrzeniem w skali CDAI [21]. Dane te kontrastują z wcześniejszymi danymi uzyskanymi przez Pettit SH i wsp., sugerującymi brak różnicy w stężeniu witaminy $\mathrm{C}$ w surowicy pomiędzy pacjentami z ChLC a osobami zdrowymi [42].

\section{WITAMINA E}

Wendland B. i wsp. ocenili stężenie witaminy E u chorych na ChLC i mimo, że jak wcześniej wspomniano, wykluczy- 
Tabela 1. Zmiany markerów stresu oksydacyjnego i antyoksydantów w ChLC.

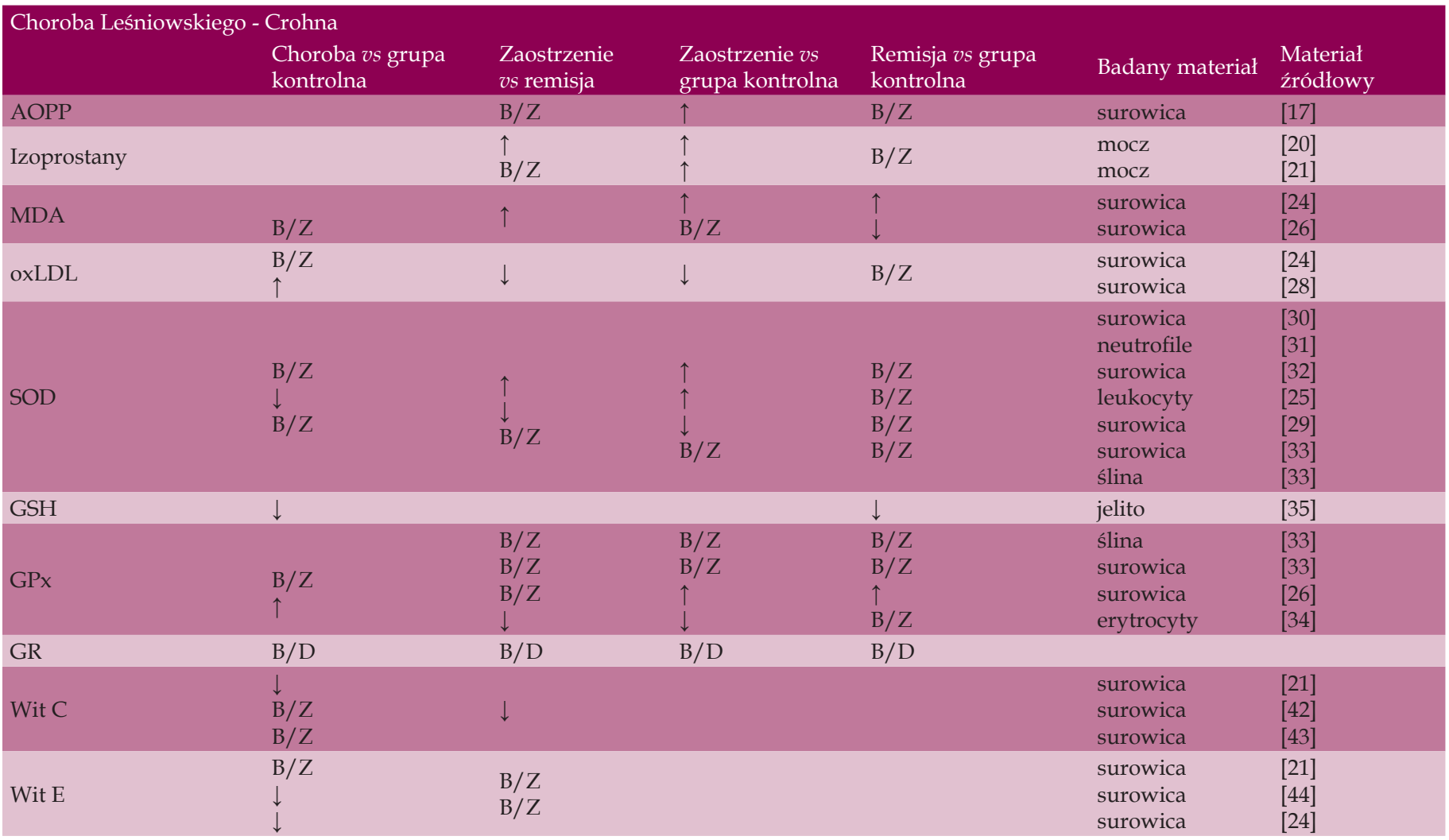

$\uparrow$ - wzrost, $\downarrow$ - zmniejszenie, B/Z - bez zmian istotnych statystycznie, B/D - brak danych literaturowych

li z grupy badanej osoby niedożywione oraz palące i poddali osoby chore ścisłej diecie, nie stwierdzili statystycznie istotnej różnicy w stężeniu witaminy E u osób chorych w porównaniu z grupą kontrolną. Wykazali natomiast istotną statycznie dodatnią korelację witaminy E z nasileniem cho- roby w skali CDAI [21]. Rezultaty te potwierdzały wyniki Hoffenberg E.J., i wsp, stwierdzające istotny wzrost stężenia witaminy E w ChLC. W przypadku WZJG nie wykazano natomiast podobnych korelacji witaminy E z zaostrzeniem procesu chorobowego [43]. Dane te jednak kontrastują z me-

Tabela 2. Zmiany markerów stresu oksydacyjnego i antyoksydantów we WZJG.

\begin{tabular}{|c|c|c|c|c|c|c|}
\hline \multicolumn{7}{|c|}{ Wrzodziejące zapalenie jelita grubego } \\
\hline & $\begin{array}{l}\text { Choroba vs grupa } \\
\text { kontrolna }\end{array}$ & $\begin{array}{l}\text { Zaostrzenie } \\
\text { vs remisja }\end{array}$ & $\begin{array}{l}\text { Zaostrzenie } v s \\
\text { grupa kontrolna }\end{array}$ & $\begin{array}{l}\text { Remisja vs grupa } \\
\text { kontrolna }\end{array}$ & Badany materiał & $\begin{array}{l}\text { Materiał } \\
\text { źródłowy }\end{array}$ \\
\hline $\mathrm{AOPP}$ & $\uparrow$ & $\uparrow$ & $\begin{array}{l}\uparrow \\
\uparrow\end{array}$ & $\begin{array}{l}\uparrow \\
\mathrm{B} / \mathrm{Z}\end{array}$ & $\begin{array}{l}\text { Surowica } \\
\text { Surowica } \\
\text { surowica }\end{array}$ & $\begin{array}{l}{[17]} \\
{[18]} \\
{[19]}\end{array}$ \\
\hline Izoprostany & $\uparrow^{*}$ & & & & & {$[22]$} \\
\hline MDA & $\mathrm{B} / \mathrm{Z}$ & & $\mathrm{B} / \mathrm{Z}$ & $\mathrm{B} / \mathrm{Z}$ & surowica & [26] \\
\hline oxLDL & $\mathrm{B} / \mathrm{D}$ & $\mathrm{B} / \mathrm{D}$ & $\mathrm{B} / \mathrm{D}$ & $\mathrm{B} / \mathrm{D}$ & & \\
\hline SOD & $\begin{array}{l}\downarrow \\
\mathrm{B} / \mathrm{Z}\end{array}$ & $\mathrm{B} / \mathrm{Z}$ & $\begin{array}{l}\downarrow \\
\mathrm{B} / \mathrm{Z}\end{array}$ & $\mathrm{B} / \mathrm{Z}$ & $\begin{array}{l}\text { neutrofile } \\
\text { surowica } \\
\text { surowica } \\
\text { erytrocyty }\end{array}$ & $\begin{array}{l}{[31]} \\
{[32]} \\
{[53]} \\
{[34]}\end{array}$ \\
\hline GSH & $\begin{array}{l}\downarrow \\
\downarrow\end{array}$ & $\mathrm{B} / \mathrm{Z}$ & & & $\begin{array}{l}\text { erytrocyty } \\
\text { jelito }\end{array}$ & $\begin{array}{l}{[37]} \\
{[38]}\end{array}$ \\
\hline GPx & $\uparrow$ & $\begin{array}{l}\mathrm{B} / \mathrm{Z} \\
\downarrow\end{array}$ & $\uparrow$ & $\begin{array}{l}\uparrow \\
\mathrm{B} / \mathrm{Z}\end{array}$ & $\begin{array}{l}\text { surowica } \\
\text { erytrocyty }\end{array}$ & $\begin{array}{l}{[26]} \\
{[34]}\end{array}$ \\
\hline GR & $\mathrm{B} / \mathrm{Z}$ & & & & jelito & [39] \\
\hline Wit C & $\mathrm{B} / \mathrm{Z}$ & & & & surowica & {$[43]$} \\
\hline Wit E & $\begin{array}{l}\mathrm{B} / \mathrm{Z} \\
\downarrow \\
\mathrm{B} / \mathrm{Z}\end{array}$ & $\begin{array}{l}\downarrow \\
\mathrm{B} / \mathrm{Z}\end{array}$ & & & $\begin{array}{l}\text { surowica } \\
\text { surowica } \\
\text { surowica }\end{array}$ & $\begin{array}{l}{[43]} \\
{[54]} \\
{[55]}\end{array}$ \\
\hline
\end{tabular}

*zapalenie jelit indukowane u myszy, $\uparrow$ - wzrost, $\downarrow$ - spadek, B/Z - bez zmian istotnych statystycznie, B/D - brak danych literaturowych 
taanalizą stężenia witamin rozpuszczalnych w tłuszczach $\mathrm{w}$ NCHZJ wykonaną przez Fabisiak N. i wsp. W przypadku witaminy E metaanaliza objęła 171 osób z ChLC i 655 osób zdrowych, co pozwoliło wykazać statystycznie istotne obniżenie jej stężenia w grupie osób chorych [44].

Zestawienie opisanych wyżej zależności parametrów stresu oksydacyjnego oraz antyoksydantów przedstawiono w Tabeli 1 dla ChLC oraz Tabeli 2 dla WZJG.

\section{PODSUMOWANIE}

Uogólniony charakter NChZJ i złożoność ich podłoża etiologicznego oraz zwiększenie ryzyka nowotworzenia przyczyniły się do wczesnego powiązania tych chorób ze stresem oksydacyjnym. Mimo upływu lat liczba dostępnych publikacji na ten temat pozostaje niewielka. Przyczyną może być właśnie złożoność tych chorób, towarzyszący im przewlekły stan zapalny z okresami zaostrzeń i remisji o różnym nasileniu. Czynniki środowiskowe jak palenie tytoniu, leki, alkohol, ksenobiotyki i wiele innych, zwiększają zarówno ryzyko rozwoju jak i zaostrzeń NChZJ [45]. Tym samym można by sądzić, że okresy nasilenia aktywności choroby powinny korelować ze stężeniem antyoksydantów, czy też markerów stresu oksydacyjnego, mimo to liczne badania prezentują często sprzeczne wyniki. Temat wydaje się szczególnie istotny, gdy coraz częściej wykazuje się prozdrowotną rolę antyoksydantów w NChZJ. W modelu WZJG indukowanego u myszy, w grupie leczonej kwasem askorbinowym wykazano ustępowanie objawów klinicznych, spadek wydzielania cytokin prozapalnych oraz stężenia produktów stresu oksydacyjnego. Aktywność antyoksydantów, wliczając w to SOD i GPx, była natomiast istotnie zwiększona [46]. W badaniach in vivo natomiast Aghdassi E. i wsp. stwierdzili znacznie obniżony poziom stresu oksydacyjnego, w tym produktów peroksydacji lipidów po 4 tygodniach suplementacji witaminy $\mathrm{E}$ i witaminy $\mathrm{C}$ w dużych dawkach (odpowiednio 800mg/dziennie i 1000 mg/dziennie). Nie wykazali natomiast różnicy w poziomie nasilenia ChLC, mierząc wg skali CDAI [47]. Co więcej, w przypadku suplementacji witaminy E wykazano zmniejszenie uszkodzenia błony śluzowej jelita, spadek stężenia TNF-a, IL-1, IL-6, MPO oraz MDA [48]. Warto również zaznaczyć, że w przypadku populacji polskiej genotyp A/C oraz polimorfizmy genu SOD1 oraz genotyp C/T i T/T genu GSHPX1 zmniejszały ryzyko zachorowania na NChZJ [49]. Badania te wyraźnie wskazują na role homeostazy oksydoredukcyjnej w rozwoju NChZJ i regulacji odpowiedzi zapalnej. To właśnie stymulacja odpowiedzi zapalnej i związane $\mathrm{z}$ nią zwiększone wydzielanie cytokin prozapalnych prowadzi do aktywacji limfocytów T, napływu neutrofilów i makrofagów do błony śluzowej jelita u osób chorych na NChZJ. W efekcie dochodzi do zwiększenia produkcji RFT, które pośrednio stymulują wydzielanie cytokin prozapalnych, w tym TNF-a, co prowadzi do uszkodzenia nabłonka jelitowego i zwiększenia jego przepuszczalności i napływu bakterii jelitowych. Bakterie w jeszcze większym stopniu nasilają napływ komórek stanu zapalnego, które to zwalczając bakterie wytwarzają RFT, prowadząc do zaburzenia równowagi oksydoredukcyjnej [50]. Również produkty peroksydacji białek mają zdolność do aktywacji odpowiedzi zapalnej. Przykładem jest AOPP, które stymuluje nie tylko wytwa- rzanie IL-8, ale również czynnika TNF-a przez monocyty, który odgrywa kluczową rolę w rozwoju NChZJ. Należy tu wspomnieć, że właśnie leczenie biologiczne, czyli przeciwciała przeciwko TNF-a, daje najlepsze rezultaty w leczeniu NChZj, zwłaszcza ich najcięższych postaci [16]. Qian W. i wsp. stwierdzili również negatywną rolę AOPP w przypadku rozwoju osteoporozy, przedstawiając dowody na zależność utraty masy kostnej i przebudowy kośćca od jego stężenia. Co więcej, dotychczasowe badania wykazały negatywne działanie AOPP jako inhibitora proliferacji i różnicowania osteoblastów [51,52]. Biorąc pod uwagę fakt znacznie nasilonej osteoporozy w przebiegu NChZJ oraz zwiększonej produkcji AOPP, która m.in. koreluje z zaostrzeniem choroby i skalą CDAI, aspekt ten wymaga dalszych badań.

Zaburzenie równowagi oksydoredukcyjnej zdaje się odgrywać znaczącą rolę nie tylko w rozwoju, ale również i zaostrzeń NChZJ. Liczne dane wskazują, że wyrównanie zaburzeń gospodarki oksydoredukcyjnej oraz ich monitorowanie stanowić może jeden $\mathrm{z}$ istotnych elementów monitorowana przebiegu klinicznego choroby. Stąd, w pracy tej podjęto próbę opisu zmian markerów stresu oksydacyjnego i antyoksydantów w oparciu o dostępne dane literaturowe.

\section{PIŚMIENNICTWO}

1. Karpińska A, Gromadzka G (2013) Stres oksydacyjny i naturalne mechanizmy antyoksydacyjne-znaczenie w procesie neurodegeneracji. Od mechanizmów molekularnych do strategii terapeutycznych. Post Hig Med Dosw 67: 43-53

2. Czajka A (2006) Wolne rodniki tlenowe a mechanizmy obronne organizmu. Nowiny Lekarskie 75: 582-586

3. Shaikh SR, Edidin M (2006) Polyunsaturated fatty acids, membrane organization, T cells, and antigen presentation. Am J Clin Nutr 84: $1277-$ 1289

4. Jones DP (2008) Radical-free biology of oxidative stress. Am J Physiol Cell Physiol 295: 849-868

5. Michalak A, Krzeszowiak J, Markiewicz-Górka I (2014) The correlations between aging of the human body, oxidative stress and reduced efficiency of repair systems. Post Hig Med Dosc 68: 1483-1491

6. Sung CC, Hsu YC, Chen CC, Lin YF, Wu CC (2013) Oxidative stress and nucleic acid oxidation in patients with chronic kidney disease. Oxid Med. Cell Longev 2013:301982

7. Pędzik A, Rysz J (2008) Stres Oksydacyjny a zjawiska patologiczne w ustroju. Diagnostyka Laboratoryjna 44: 363-369

8. Pradedova E, Isheeva OD, Salyaev RK (2011) Classification of the antioxidant defense system as the ground for reasonable organization of experimental studies of the oxidative stress in plants. Russ J Plant Physiol 58: 210-217

9. Fukai T, Ushio-Fukai M (2011) Superoxide dismutases: role in redox signaling, vascular function, and diseases. Antioxid Redox Signal 15: 1583-1606

10. Łukaszewicz-Hussain A (2003) Rola glutationu i enzymów z nim związanych $\mathrm{w}$ procesach antyoksydacyjnych organizmu Med Pracy 54: 473-479

11. Shang F, Lu M, Dudek E, Reddan J, Taylor A (2003) Vitamin C and vitamin $\mathrm{E}$ restore the resistance of GSH-depleted lens cells to $\mathrm{H}_{2} \mathrm{O}_{2}$. Free Radic Biol Med 34: 521-530

12. Bendich A, Machlin LJ, Scandurra O, Burton GW,Wayner DDM(1986) The antioxidant role of vitamin C. Adv Free Radic Biol Med 2: 419-444

13. Oudemans-van Straaten HM, Spoelstra-de Man AM, de Waard MC (2014) Vitamin C revisited. Crit Care 18: 460

14. Gonzalez E, Bajo MA, Carrero JJ, Lindholm B, Grande C, Sánchez-Villanueva R, Del Peso G, Díaz-Almirón M, Iglesias P, Díez JJ, Selgas R (2015) An increase of plasma advanced oxidation protein products lev- 
els is associated with cardiovascular risk in incident peritoneal dialysis patients: a pilot study. Oxid Med Cell Longev 2015:219569

15. Witko-Sarsat V, Friedlander M, Capeillère-Blandin C, Nguyen-Khoa T, Nguyen AT, Zingraff J, Jungers P, Descamps-Latscha B. (1996) Advanced oxidation protein products as a novel marker of oxidative stress in uremia. Kidney Int 49: 1304-1313

16. Witko-Sarsat V, Gausson V, Descamps-Latscha B (2003) Are advanced oxidation protein products potential uremic toxins? Kidney Int 63: 1114

17. Krzystek-Korpacka M, Neubauer K, Berdowska I, Boehm D, Zielinski B, Petryszyn P, Terlecki G, Paradowski L, Gamian A (2008) Enhanced formation of advanced oxidation protein products in IBD. Inflamm Bowel Dis 14: 794-802

18. Alagozlu H, Gorgul A, Bilgihan A, Tuncer C, Unal S. (2013) Increased plasma levels of advanced oxidation protein products (AOPP) as a marker for oxidative stress in patients with active ulcerative colitis. Clin Res Hepatol Gastroenterol 37: 80-85

19. Baskol M, Baskol G, Koçer D, Ozbakir O, Yucesoy M. (2008) Advanced oxidation protein products: a novel marker of oxidative stress in ulcerative colitis. J Clin Gastroenterol 42: 687-691

20. Cracowski JL, Bonaz B, Bessard G, Bessard J, Anglade C, Fournet J (2002) Increased urinary F 2-isoprostanes in patients with Crohn's disease. Am J Gastroenterol 97: 99

21. Wendland BE, Aghdassi E, Tam C, Carrrier J, Steinhart AH, Wolman SL, Baron D, Allard JP (2001) Lipid peroxidation and plasma antioxidant micronutrients in Crohn disease. Am J Clin Nutr 74: 259-264

22. Stucchi AF, Shofer S, Leeman S, Materne O, Beer E, McClung J, Shebani K, Moore F, O'Brien M, Becker JM (2000) NK-1 antagonist reduces colonic inflammation and oxidative stress in dextran sulfate-induced colitis in rats. Am J Physiol Gastrointest Liver Physiol 279: 1298-1306

23. Traverso N, Menini S, Maineri EP, Patriarca S, Odetti P, Cottalasso D, Marinari UM, Pronzato MA (2004) Malondialdehyde, a lipoperoxidation-derived aldehyde, can bring about secondary oxidative damage to proteins. J Gerontol A Biol Sci Med Sci 59: 890-895

24. Boehm D, Krzystek-Korpacka M, Neubauer K, Matusiewicz M, Paradowski L, Gamian A (2012) Lipid peroxidation markers in Crohn's disease: the associations and diagnostic value. Clin Chem Lab Med 50: 1359-66

25. Beltran B, Nos P, Dasí F, Iborra M, Bastida G, Martínez M, O'Connor JE, Sáez G, Moret I, Ponce J (2009) Mitochondrial dysfunction, persistent oxidative damage, and catalase inhibition in immune cells of naive and treated Crohn's disease. Inflamm Bowel Dis 16: 76-86

26. Tüzün A, Erdil A, Inal V, Aydin A, Bağci S, Yeşilova Z, Sayal A, Karaeren N, Dağalp K (2002) Oxidative stress and antioxidant capacity in patients with inflammatory bowel disease. Clin Biochem 35: 569-572

27. Chen C, Khismatullin DB (2010) Oxidized low-density lipoprotein contributes to atherogenesis via co-activation of macrophages and mast cells. PLOS One 10: e0123088

28. Grip O, Janciauskiene S, Lindgren S (2004) Circulating monocytes and plasma inflammatory biomarkers in active Crohn's disease: elevated oxidized low-density lipoprotein and the anti-inflammatory effect of atorvastatin. Inflamm Bowel Dis 10: 193-200

29. Iborra M, Moret I, Rausell F, Bastida G, Aguas M, Cerrillo E, Nos P, Beltrán B (2011) Role of oxidative stress and antioxidant enzymes in Crohn's disease. Biochem Soc Trans 39: 1102-6

30. Alzoghaibi MA, Al-Mofleh IA, Al-Jebreen AM (2014) Antioxidant activities for superoxide dismutase in patients with Crohn's disease. J Basic Clin Physiol Pharmacol 25: 59-62

31. Verspaget H, Peña AS, Weterman IT, Lamers CB (1988) Diminished neutrophil function in Crohn's disease and ulcerative colitis identified by decreased oxidative metabolism and low superoxide dismutase content. Gut 29: 223-228

32. Mohammadi E, Qujeq D, Taheri H, Hajian-Tilaki K (2017) Evaluation of serum trace element levels and superoxide dismutase activity in patients with inflammatory bowel disease: Translating basic research into clinical application. Biol Trace Elem Res 177: 235-240
33. Szczeklik K, Krzysciak W, Domagala-Rodacka R, Mach P, Darczuk D, Cibor D, Pytko-Polonczyk J, Rodacki T, Owczarek D (2016) Alterations in glutathione peroxidase and superoxide dismutase activities in plasma and saliva in relation to disease activity in patients with Crohn's disease. J Physiol Pharmacol 67: 709-715

34. Krzystek-Korpacka M, Neubauer K, Berdowska I, Zielinski B, Paradowski L, Gamian A (2010) Impaired erythrocyte antioxidant defense in active inflammatory bowel disease: impact of anemia and treatment. Inflamm Bowel Dis 16: 1467-1475

35. Iantomasi T, Marraccini P, Favilli F, Vincenzini MT, Ferretti P, Tonelli F (2014) Glutathione metabolism in Crohn' s Disease. Biochem Med Metab Biol 53: 87-91

36. Miralles-Barrachina O, Savoye G, Belmonte-Zalar L, Hochain P, Ducrotté P, Hecketsweiler B, Lerebours E, Déchelotte P (1999) Low levels of glutathione in endoscopic biopsies ofpatients with Crohn's colitis: the role of malnutrition. Clinical Nutrition 18: 313-317

37. Rana S, Sharma S, Prasad KK, Sinha SK, Singh K. (2014) Role of oxidative stress \& antioxidant defence in ulcerative colitis patients from north India. Indian J Med Res 139: 568

38. Ruan E, i wsp (1997) Glutathione in the idiopathic inflammatory bowel diseases: relationship between colonic glutathione levels and inflammation. Nutr Res 17: 463-473

39. Ziegler RZ, Chang SC, Leitzmann MF, Johnson KA, Johnson C, Buys SS, Hoover RN, Ziegler RG (2006) Folate intake, alcohol use, and postmenopausal breast cancer risk in the Prostate, Lung, Colorectal, and Ovarian Cancer Screening Trial. Am J Clin Nutr 83: 895-904

40. Imes S, Dinwoodie A, Walker K, Pinchbeck B, Thomson AB (1986) Vitamin C status in 137 outpatients with Crohn's disease. Effect of diet counseling. J Clin Gastroenterol 8: 443-446

41. Filippi J, Al-Jaouni R, Wiroth JB, Hébuterne X, Schneider SM. (2006) Nutritional deficiencies in patients with Crohn's disease in remission. Inflamm Bowel Dis 12: 185-191

42. Pettit SH, Shaffer JL, Johns CW, Bennett RJ, Irving MH (1989) Ascorbic acid absorption in Crohn's disease. Dig Dis Sci 34: 559-566

43. Hoffenberg EJ, Deutsch J, Smith S, Sokol RJ (1997) Circulating antioxidant concentrations in children with inflammatory bowel disease. American J ClinNutr 65: 1482-1488

44. Fabisiak N, Fabisiak A, Watala C, Fichna J (2017) Fat-soluble Vitamin Deficiencies and Inflammatory Bowel Disease. J Clin Gastroenterol 51 878-889

45. Tian T, Wang Z, Zhang J (2017) Pathomechanisms of oxidative stress in inflammatory bowel disease and potential antioxidant therapies. Oxid Med Cell Longev 2017: 4535194

46. Yan H, Wang H, Zhang X, Li X, Yu J (2015) Ascorbic acid ameliorates oxidative stress and inflammation in dextran sulfate sodium-induced ulcerative colitis in mice. Int J Clin Exp Med 8: 20245-20253

47. Aghdassi E, Wendland BE, Steinhart AH, Wolman SL, Jeejeebhoy K, Allard JP. (2003) Antioxidant vitamin supplementation in Crohn's disease decreases oxidative stress: a randomized controlled trial. Am J Gastroenterol 98: 348-353

48. Tahan G, Aytac E, Aytekin H, Gunduz F, Dogusoy G, Aydin S, Tahan V, Uzun H (2011) Vitamin E has a dual effect of anti-inflammatory and antioxidant activities in acetic acid-induced ulcerative colitis in rats. Can J Surg 54: 333

49. Mrowicka M, Mrowicki J, Mik M, Wojtczak R, Dziki L, Dziki A, Majsterek I (2017) Association between SOD1, CAT, GSHPX1 polymorphisms and the risk of inflammatory bowel disease in the Polish population. Oncotarget 8: 109332

50. Piechota-Polanczyk A, Fichna J (2014) The role of oxidative stress in pathogenesis and treatment of inflammatory bowel diseases. Naunyn-Schmiedeberg Arch Pharmacol 387: 605-620

51. Wu Q, Zhong ZM, Pan Y, Zeng JH, Zheng S, Zhu SY, Chen JT (2015) Advanced oxidation protein products as a novel marker of oxidative stress in postmenopausal osteoporosis. Med Sci Monit 21: 2428

52. Zhong ZM, Bai L, Chen JT (2009) Advanced oxidation protein products inhibit proliferation and differentiation of rat osteoblast-like cells via NF-kappaB pathway. Cell Physiol Biochem 24: 105-14 
53. Matusiewicz M, Neubauer K, Lewandowska P, Gamian A, Krzystek-Korpacka M (2017) Reduced Transferrin Levels in Active Inflammatory Bowel Disease. BioMed Res Int 2017: 9541370

54. D'Odorico SB, Cardin R, D'Inca' R, Martines D, Ferronato A, Sturniolo GC (2001) A, Reduced plasma antioxidant concentrations and incre- ased oxidative DNA damage in inflammatory bowel disease. Scand J Gastroenterol 36: 1289-1294

55. Ramakrishna B, Varghese R, Jayakumar S, Mathan M, Balasubramanian KA (1997) Circulating antioxidants in ulcerative colitis and their relationship to disease severity and activity. J Gastroenterol Hepatol 12: $490-494$

\section{Oxidative stress in etiopathogenesis of inflammatory bowel diseases}

\section{Michał Kloska ${ }^{1,2}$, Dorota Mańkowska-Wierzbicka², Magdalena Człapka-Matyasik ${ }^{3}$, Agnieszka Dobrowolska², Marian Grzymisławski²}

${ }^{1}$ Department of Medicine, Lehigh Valley Health Network, Allentown, Pennsylvania, USA

${ }^{2}$ Department of Gastroenterology, Dietetic Nutrition and Internal Diseases, Poznan University of Medical Sciences

${ }^{3}$ Faculty of Food Science and Nutrition, Department of Human Nutrition and Hygiene, Poznan University of Life Sciences

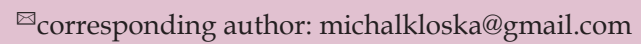

Key words: Inflammatory bowel diseases, oxidative stress, antioxidants, free radicals, reactive oxygen species.

\section{SUMMARY}

Inflammatory bowel diseases are a group of chronic diseases of the digestive tract of unknown origin. The etiology of IBD is multifactorial and involves interaction between genetic, environmental and immunological factors with oxidative stress being an inherent part of any one of them. Therefore, the redox equilibrium is crucial to maintain cell homeostasis in the gastrointestinal (GI) tract, which is constantly exposed to large numbers of commensal and pathological bacteria. Distortion of this homeostasis and increase in oxidative stress leads to the propagation of inflammation, mucosal injury in the GI tract and is associated with the development and exacerbation of IBD. 